\title{
O WIDZENIU W NATURZE
}

Norbert Elias

\section{/// 1 .}

(...) Widzenie w naturze wydaje się w gruncie rzeczy najprostszą sprawą na świecie: wędrując, cieszymy się zmiennościa krajobrazu, wspinamy na góry i radujemy pięknymi widokami. Aby nauczyć się widzieć sztukę, trzeba usilnej pracy nad każdym szczegółem - krajobraz natomiast zdaje się udostępniać oku całe swoje piękno bezpośrednio i bez wysiłku. Mimo tej różnicy dzieło malarstwa ma z widokiem przyrody wiele wspólnego - nie bez racji nazywamy jedno i drugie „obrazem”, i tu, i tam bowiem postrzegające Ja staje naprzeciw czegoś, czego piękno podlega ocenie. W wypadku malowidła widoczne jest jednak natychmiast, z jakichś powodów jeden element przedstawienia (drzewo, człowiek lub budynek) łączy się z innym w pewną malarską całość, bo przecież to wyobraźnia artysty tak go umieściła. W wypadku krajobrazu natomiast nie da się w ogóle zrozumieć, jak to się stało, że rzeka i drzewo, góra i dolina, droga i wioska uzupełniają się również nawzajem, tworząc obrazową całość. Co zaś jeszcze bardziej zdumiewające, nie ma przecież krajobrazu zupełnie brzydkiego, gdy tymczasem niezliczone obrazy, którym brakuje tej jedności, zmuszeni jesteśmy potępiać jako bezwartościowe.

A przecież to właśnie ta konieczność starannej oceny niskiej wartości malarskiej obrazu, nie zaś wartości krajobrazu, która wydaje się ciagle taka sama, daje co najmniej jeden silny impuls do zbadania, jak widok określonego obrazu ma się do autentyczności jego danego przedstawienia i do jego włączenia w porządek całości. Z obserwacji tego, co poszczególne, wyrasta bowiem stopniowo wgląd w wartość dzieła sztuki. W odniesieniu do krajobrazu otwarte pozostaje zaś pytanie, gdzie szukać tutaj owych obserwowalnych szczegółów, których określony stosunek i włączenie w porządek całości zasługiwałyby na zbadanie w tym sensie, że pozwoliłyby nam nauczyć się widzieć całość na nowo i w głębszych jej warstwach. Zawsze są wokół nas krzewy, morza i kwiaty, i to w wielu 
gatunkach i odcieniach, ale krzew pozostaje krzewem, kwiaty - kwiatami, a morze - morzem: co jeszcze można by się tu nauczyć widzieć? W szystko to w swojej całości, czyli krajobraz, zdaje się bardziej bezpośrednio możliwe do uchwycenia niż dzieło sztuki.

\section{/// 2.}

Jest dziś oczywiste, że wędrując, postrzegamy naturę w jej pięknie, czyli z estetycznego punktu widzenia, a mianowicie jako krajobraz. Tylko niekiedy zdajemy sobie sprawę z tego, że takie sposoby oglądania narodziły się dopiero stopniowo w wiekach Odrodzenia.

Zwykło się mówić o tych czasach jako o wieku budzącej się indywidualności, mając na myśli, że osobowości nie tylko odgrywały tutaj z cała powaga swoje role, lecz były ponadto świadome siebie jako odizolowanej, swoistej osobności. Ta świadomość, którą dziś bez namysłu uważamy za stan człowieka w ogóle, oczywisty sam przez się, charakteryzuje tak naprawdę postawę nowożytna. Dopiero ta świadomość ściśle skrępowanego swoim losem Ja, które oddzielone jest jakby przepaścią od każdego Ty i całego świata, przetworzyła naturę w krajobraz. Cichym założeniem każdego oglądu krajobrazu jest bowiem, że postrzegający ogląda coś poza sobą samym, co wciąż pozostaje w oznaczonej odległości od jego Ja. Wówczas, gdy naturę zaczęto widzieć jako obraz stający przed człowiekiem, można było wpaść na pomysł przedstawienia jej jako obrazu, przeniesienia trójwymiarowej przestrzeni natury na płaszczyznę obrazu i perspektywicznego rozszerzenia przestrzeni dzieła. Od tego czasu człowiek widział naturę jako krajobraz, a przestrzeń natury postrzegał opacznie na wzór przestrzeni obrazu. Aby wykazać, że to, co oczywiste samo przez się, jest w istocie zaledwie osobliwością czasów nowożytnych, trzeba uwydatnić ową swoistość, przeciwstawiając jej inny poziom świadomości i wynikającego z niego widzenia natury.

\section{/// 3 .}

Każdy, kto pragnąby wkroczyć w pełen dziwów świat Greków, musiałby zastanowić się, jak to się stało, że ci ludzie, żyjący wszak w najściślejszym związku z natura, nigdy właściwie nie malowali krajobrazu, pomijając już to, że nie mieli słowa na to nieznane im pojęcie. Równie szczególne jest to, że kultura ta, obfitująca przecież w jedyne w swoim rodzaju, silne osobowości, nie znała pojęcia osobowości.

Wszystkie konstrukcje i wykładnie greckiej spuścizny w najlepszym razie psuja głębsze poczucie greckiej postawy, ponieważ nie zauważaja 
następującego zagadnienia: Hellen nigdy nie postrzegał siebie samego jako całkowicie i zupełnie odosobnionego, ostro odrębnego od innych przez swoją świadomość, lecz w owej świadomości czuł się - pomimo wszystkich różnic i przeciwieństw - jednością z innym i odczuwał świat jako jedność, ujętą w jeden wieczny porządek wszechrzeczy. Człowiekowi żyjącemu z taką myślą o kosmosie obca była więc także kwestia, którą zadręczaja się czasy późniejsze: tutaj samotne Ja, tam obca wszechrzecz. Noein, phronein, myślenie w ogóle nie było dla Greków - jak się to dziś często wydaje - subiektywną zdolnością jednostki, lecz prawidłowością i porządkiem. Jasne staje się w ten sposób, że w punkcie kulminacyjnym greckiej tradycji Platon nie stawia pytania o poznanie dobra i prawdy tak, jak jesteśmy do tego przyzwyczajeni, czyli tutaj poznające Ja, a tam ciemny świat, który ma być poznany. Jego pytanie dotyczy bytu dobra i prawdy, które są bytem, tak samo jak „są" byty takie jak człowiek, liczba lub idea.

Dla naszej mentalności pozostaje zagadką greckiej postawy, którą rozwiązać można dopiero na gruncie myślenia takiego jako powyższe, to, że Grecy tym samym ożywczym spojrzeniem, którym patrzyli na igrzyska olimpijskie, ożywiali również drzewo, górę i niebo. Natura była dla nich w równie małym stopniu krajobrazem, widokiem do zagarnięcia, jak bieg młodzieńców, zgromadzenie ludowe, codzienny ruch Pireusu czy wystawienie tragedii. Nie chcemy przecież zapominać, że ich statuy nie były wykute na to, by w muzeach same w sobie stanowiły piękny widok, lecz ich sens dopełnia się dopiero wówczas, gdy zyskują związek z codziennym życiem poprzez bardzo konkretne otoczenie: jako wizerunki bogów w świątyniach, jako ozdoba ulic i domów. Także znaczenie hymnów Pindara opiewających zwycięzców igrzysk jest wattpliwe i puste mimo całego przepychu mowy i rytmu, jeśli ktoś przywykł chwalić zwycięzców z tytułu ich pięknego wyglądu, dobrej sylwetki, ponieważ zwyciężyli w jakiegoś rodzaju przedstawieniu, jakim sa najczęściej nasze imprezy „sportowe”, albo pobili jakiś mierzalny rekord, który ofiarują napiętym nerwom widzów. Pindar natomiast opiewa ich, ponieważ zwycięskie życie zasługuje na chwalbę, ponieważ poeta, któremu bóg użyczył swojego daru, ma radosny obowiązek wynosić ponadprzeciętne życie pod niebiosa i sławić na całej ziemi ze względu na nie samo. Pieśni te potwierdzaja nam też, jak mało zależało Grekom na pojedynczym człowieku o takich to a takich cechach. Wielbią oni bowiem zwycięzców ze względu na ich obiektywne dokonanie, ze względu na wolę zwycięstwa, a nie z powodu osobistych zalet. Opiewaja go zatem - przy wszystkich różnicach - z podobnych 
pobudek jak Homer wędrówkę Odysa lub zbroję Achillesa, dzieło Hefajstosa (...). Kiedy Grecy opowiadaja, jak Demeter, matka ziemi, odziana w ciemne szaty idzie przez pola, poszukując pośród lamentów swojej porwanej przez Hadesa córki przy pełgającym świetle pochodni, w swoim pierwotnym sensie jest to zatem w równie małym stopniu obraz, jak symbol: jest w tym to samo życie, którym żyli oni sami. Nawet w najbardziej codziennych obrazach kultury helleńskiej widoczna jest ta sama orientacja świadomości, z której wyrastała wyrafinowana myśl o kosmosie jako jednym świecie, ukształtowanym przez jeden ład zdobny jednym pięknem. Aby jednak nie zmieniło się to znowu w bajkę o nieustającym weselu Greków, trzeba w kilku słowach wskazać, że prawo to niezbywalnie i nieuniknienie włada również ludźmi, co pozwalało rozumnemu człowiekowi pojąć, jaki rodzaj przemocy nazywali Grecy losem. Można więc na tej podstawie zasadnie stwierdzić, że lud ten nie wyznawał bynajmniej jak mu się to nazbyt często przypisuje - żadnej religii spinozjańskiej czy panteistycznej, lecz żył z natura w intymny sposób, który był zupełnie swoisty i niemożliwy do opisania za pomoca jednego hasła. Należy go raczej rozumieć całkiem po prostu, taki bowiem był, o czym świadczy szeroki zakres pojęcia physis.

\section{/// 4.}

Niebezpieczeństwo studiów historycznych tkwi w tym, że albo badacz błędnie sytuuje siebie samego i swój świat u podstawy poprzednich, albo też przeciwnie: gdy tylko rzeczy obce i niezwykłe stają mu na przeszkodzie, pospiesznie pali mosty i oznajmia, że nie ma już żadnej drogi zrozumienia, choć może właśnie starannie przemyślana praca nad tym, co niespotykane, mogłaby przynieść wiele pożytku. Wielu - nawet najuczeńszych - badaczy, których zwodzą ścisłe więzi, jakimi połączone sa kultury europejskie z kultura grecką jako najważniejszym punktem wyjścia ich tradycji, popełnia błąd polegający na tym, że to, co znamienne dla nas, przypisujemy z założenia również Grekom. Badacze mniej staranni, którzy chętnie wprawiają nas w zdumienie zagadkami, ulegaja z kolei raczej błędowi drugiego rodzaju. Ktoś obdarzony subtelniejszym słuchem i kierujący się wyważonymi zasadami uda się natomiast drogą środka, której celem będzie zbliżenie przeszłości do teraźniejszości, by ta stanęła nam przed oczyma w całej swojej swoistości czy wręcz obcości. Komu zaś powiedzie się zadanie ujęcia w ten sposób przeszłości na nowo, ten napełni ją nowym życiem, zarazem zaś z wielkim pożytkiem podąży jej śladem naprzód. Być może nie od razu zupełnie jasne jest, dlaczego „widzenie 
w naturze" rozpoczęło się od szczegółowego omówienia greckiego sposobu widzenia. W tym miejscu musi jednak wystarczyć uwaga, że ten, kto uprzytomni sobie dogłębnie sens owej innej postawy, owego postrzegania czysto krajobrazowego i prezentacyjnego, znalazł się co najmniej na drodze do zrozumienia czegoś nowego. Trzeba bowiem jasno powiedzieć sobie jedno: widzenie w naturze nie jest bynajmniej sprawą tak prosta, gdyż łaczy się w jedno z tym, jak człowiek widzi samego siebie i świat w ogólności. Jednym słowem, pozostaje ono w najściślejszym związku z cała swoistością kultury. Konieczne będzie więc również ujęcie natury - podobnie jak każdego innego dobra kultury - w dziedzinie wychowania.

\section{/// 7.}

(...) W odniesieniu do wychowania i nauki podstawową zasadą wszelkiej pedagogiki okazuje się zatem: tam, gdzie się wychowuje, tam stawia się pytania; pytania o to, czym jest granit, ale i o to, czym jest „kłamstwo”. Zagadnienia etyczne wciąż zupełnie niesłusznie oddziela się od innych problemów naukowych. Dopiero gdy wciąż na nowo wykazujemy, że sens mają w ogóle tylko odpowiedzi uzasadnione naukowo, a to o tyle, o ile roszcza pretensje do prawdy, możemy unaocznić, w jakim sensie kogoś, kto dla korzyści własnej, z rozmysłem lub z przemądrzalstwa przeinacza prawdę, można nazwać nieprawdomównym i kłamcą. Tylko gruntownie przemyślana praca naukowa daje możliwość przezwyciężenia płytkiego ślizgania się po powierzchni, próżnego i powierzchownego łgarstwa i osiągnięcia owej rzeczowej, głębokiej i wnikliwej jasności, która musi być wprawdzie nie ostatecznym, ale z pewnością jednym z najistotniejszych celów każdego nauczania i każdego wychowania. Tylko bowiem starannie wypracowane umiejętności i wnikliwa wiedza przydają spokojnej pewności postawie, która gotowa jest przyznać się do błędu, dlatego że nie potrzebuje być tak próżna, by kłamać, gdyż jej zamiarem nie jest zabezpieczenie kulejącej godności osobistej, lecz zdążanie do prawdy. Jest to więc świadomość własnego obiektywnego dokonania, które jedynie może położyć tamę jakże często uprawianym gierkom samozadowolenia i użycza nam tak pożądanej pewności.

\section{/// 8.}

Ten przegląd powinien wystarczyć, by wykazać, jak na przykładzie wychowania do widzenia w naturze przedstawić można zasady wszelkiego wychowania! Dzięki temu też zrozumiały staje się wywód, który dotąd można było uznać za zbędną dygresję, a mianowicie uwaga na temat Greków. 
Kto bowiem nauczył się w ten sposób oceniać i widzieć zdarzenia i związki przyrodnicze, ten na wyższym poziomie od dawna przekroczył już owo pęknięcie pomiędzy Ja i światem. Jego postawa musi się umocnić, gdy rozpozna u Greków orientację pod wieloma względami odmienna, ale podobną w myśleniu o jednym, wszechogarniającym porządku.

W tym punkcie staje się zresztą również jasne, jak daleko postapiliśmy naprzód w porównaniu z Grekami. Podobnie jak grecki kosmos ujęty był w ramy tego najzupełniej boskiego porządku, tak też i my łączymy i porządkujemy, lecz po stokroć bardziej, postępując od ciagle nowych szczegółów ku nowym rozróżnieniom i powiązaniom, odpowiednio do rozgałęzienia i zróżnicowania metod naukowych. Jeśli pytamy o własności kamienia tylko jako masy określonej ilościowo, czyli na przykład w kontekście do siły ciążenia, otrzymujemy odpowiedź na gruncie teorii fizykalnej. Jeśli zapytamy o jego skład substancjalny, umieścimy go w porządku teorii chemicznych wraz z kwasami, zasadami, alkoholami i tłuszczami. Jeśli zapytamy o jego wiek, znaczenie jego warstw, rozwiązania musi dostarczyć teoria geologiczna. Tak zatem, jak niezliczone rozgrywki pomiędzy pytaniem a odpowiedzią układają się w porządek w sensie jakiejś teorii poprzez różnorodne, oddzielone od siebie metody naukowe, tak też te ostatnie, jak pokazuje przykład fizyki, chemii i historii ziemi, przy każdym czystym podziale okazują się jednak mniej lub bardziej ściśle ze sobą powiązane, a łączą się w jedno jako ogniwa systemu nauki lub, co na jedno wychodzi, w idei nauki, która stanowi podwalinę ich wszystkich. Zrozumiałe staje się zatem, że jest ona obszarem znaczeń w swoim własnym rodzaju, który istnieje obok obszarów sztuki, religii, prawa itp. Ogół tych obszarów znaczących w jakikolwiek sposób, czyli system wszystkich obszarów znaczenia, to właśnie idea wszechrzeczy, kosmosu, całości, o której powiedzieliśmy powyżej, że trzeba się nauczyć widzieć jej poszczególne elementy, aby rozpoznać związki, które spajaja je w całość. Jeśli więc udało się za pomoca wszystkiego tego, co zostało tu powiedziane, pokazać, jak ogląd całości czyni płodnym przedstawienie poszczególnych elementów i jak pogłębienie relacji między poszczególnymi cząstkami kształtuje z kolei głębszy i dalej sięgający ogląd całości, jeśli udało się jasno uświadomić ten nieskończony proces rozwoju wszystkiego, co istnieje, to widać tym samym, dlaczego wyszliśmy od Greków. Kosmos Greków jest bowiem skończony, statyczny. Obrazem natomiast, przez który my pragnęlibyśmy poddać ideę wszechrzeczy oglądowi, nie jest zamknięta w skończonych granicach, spoczywająca w nieporuszonym spokoju kula, pod postacią której Parmenides wyobrażał sobie prawdziwy byt (a która 
dla niego z pewnością nie była żadnym obrazem). My unaoczniamy sobie uporządkowany świat $\mathrm{w}$ postaci kuli, która od punktu środkowego rozszerza swój zasięg w nieskończoność, coraz pojemniejsza, coraz bardziej podzielona. Treść porządku można uchwycić dopiero, gdy pojmiemy, że nie jest on żadnym nieruchomym i krępującym wszystko szkieletem budowy świata, lecz umożliwia relacje i spojrzenia na wszystkie strony bez końca, gdy pojmiemy, że w nieustannym procesie porządku wciąż na nowo kształtuje się byt, że zatem powierzchnia kuli rozpina się coraz wyżej i wyżej. Wówczas dopiero można w pełni uchwycić sens pracy wychowawczej, która opiera się na naukach postępujących wiecznie naprzód stosownie do swojej idei, a na wszystkie strony kieruje spojrzenie dostrzegające nieskończenie rozczłonkowany porządek. Niech więc w ten sposób, polegający na starannym rozważaniu podobieństw i różnic, odwołanie do Greków przyniesie nam pożytek, a zarazem stwierdzona zostanie z wdzięcznością niewyczerpana doniosłość Platona, ich największego myśliciela.

\section{/// 9 .}

Oprócz niego dwaj inni ludzie wskazali drogę do wszystkiego tego, co zostało tutaj powiedziane, gdy na przykładzie natury jako przedmiotu wychowania zostały przedstawione także zasady wychowania w ogóle: Kant i Goethe. Ich życie i dzieła stanowiły w mniejszym lub większym stopniu punkt wyjścia tej tradycji wychowawczej, zatem należy je tu wymienić nie tylko w wyrazie czci, lecz również dlatego, że wymaga tego sam temat. Wyczerpujące omówienie Kanta w tym miejscu nie miałoby wielkiego sensu. Ci, którzy znają dziedzinę metody transcendentalnej, będą głębiej rozumieć mój wywód już przez sam ład w myśleniu, który wywołuje wspomnienie jego pracy. Mam tu na myśli zwłaszcza to, co dotyczy pojęć i relacji między idea, prawem, oglądem i nauką. Dla pozostałych zaś omawianie go tutaj byłoby wznoszeniem zamków na piasku.

Można natomiast zasadnie wymagać od każdego, kto chce nieść i przekazywać kulturowe wartości, a zatem od każdego wychowawcy, by znał dzieło i znaczenie życia Goethego. Można więc w kilku słowach wskazać na jego rozważania o naturze jako na praktyczną ilustrację tego, co przedstawiono powyżej.

Niemal każdy artysta - czy to potraktowany z osobna, czy w ogóle a w każdym razie każda epoka w kulturze nowożytnej wydobywali jakiś określony krajobraz z pełni przyrody i darzyli jego wyobrażenie szczególna miłością, ponieważ odpowiadał on najlepiej ich szczególnemu nastawieniu kulturowemu. Przypomnijmy sobie choćby pejzaż klasyczny, 
archipelag Hölderlina, pejzaż romantyczny Wertera Goethego, wreszcie krajobraz „naturalistyczny” (by użyć tu tego paradoksalnego określenia), jaki odmalowuje Flaubert. Goethe zaś, skoro już pozostawił za sobą romantyzm, nigdy nie przedstawiał krajobrazu w ścisłym, czysto malarskim sensie słowa. Jego kunszt, który nawiązuje do Grecji daleko bardziej nawet niż klasycyzm Winckelmanna, dąży do zachowania prawidłowości przez własny ogląd w spokojnej, poświęconej nauce pracy, czyli - zgodnie z jego idea - do zrozumienia całości przez szczegół. Silny dostojeństwem swoich coraz doskonalszych miar, w dziełach okresu dojrzałego, czyli w podróży włoskiej czy w Wilhelmie Mistrzu, przypisuje on naturze tę samą nieuchwytność, co wszystkiemu, co ludzkie lub ludzkiemu pokrewne. Lecz swoboda duchowa, z jaką posługiwał się tymi miarami, jasna, grecka poglądowość, z jaka przenosił on teorię i wypróbowywał ja w doświadczeniu, owo otwarte, plastyczne widzenie jest najcudowniejszą zdobyczą jego osobowości.

Pomimo wszystkich błędów, właściwych owym czasom, życie Goethego jako człowieka pokazuje nam przede wszystkim jedno: jak ktoś, komu świat jawi się jedynie niewyraźnie, skryty w mroku uczuć, musi z konieczności również sam być dogłębnie nieczuły i próżny przeżyć. W im rozmaitszy sposób jest zaś zbudowany świat zewnętrzny, im bardziej różnorodnym i zróżnicowanym jawi mu się byt w swoim uporządkowaniu, tym bogatsze, a przez to i pełniejsze staje się ludzkie „wnętrze”. W miarę jak zewnętrze i wnętrze potęguja się we wzajemnej relacji, staje się na nowo oczywiste, z jakich powodów Ja, które czuje się oddzielone przepaścia od świata i wydane jedynie na ćmienie przytępionych uczuć, zamykając oczy na żyzną zewnętrzność, pozostaje skamieniałe, ubogie i puste. Wychowanie, które nie przekracza tego pęknięcia, stanowiącego podstawę każdego widzenia czysto krajobrazowego, pozostaje zatem miałkie i puste. Dopiero wychowanie, które ściąga ku sobie całą masę materii świata i czyni je przez to użytecznym we własnym rozumieniu, stosownie do własnych zasad, za pośrednictwem form, w jakich materia ta jest wciąż na nowo porządkowana przez nieustannie postępujące naprzód nauki, wypełnia zadanie kształcenia. W obliczu zaś takiego bogactwa jakikolwiek niedostatek treści jest nie do pojęcia.

\section{/// 10.}

Każde wychowanie przez kogoś innego, nawet jeśli dostapiło już tego stopnia jasności co do własnego sensu, niesie ze soba pewne ostatnie niebezpieczeństwo, którego nie sposób przecenić. A mianowicie: ktoś, kto 
w młodości pozostawał pod wpływem szeregu wychowawców, łatwo pozostaje na tyle przyzwyczajony do korzystania ze wsparcia innych i do pozostawiania im odpowiedzialności za własne czyny, że u kresu tego trudu wzdraga się działać na podstawie własnego postanowienia. Tam zaś, gdzie zmuszony jest do odpowiedzialnego działania, w okropnej niepewności unika decyzji albo też wpada w ręce pierwszego lepszego, który potrafi wykorzystać jego słabości, ulegając wpływowi lepszych lub gorszych wychowawców. Wychowanie musi zatem, w miarę swoich postępów, coraz usilniej obstawać przy tym, by coraz bardziej świadomie przekazywać wychowywanemu odpowiedzialność za jego własne czyny i dążenia. Ma uczyć go odróżniać dobro od zła, piękno od szpetoty, prawdę od fałszu - ale miary pozostaną bezużytecznym drewnem, gdy tak nauczany nie będzie umiał ich nieustannie na nowo sprawdzać we własnym doświadczeniu i myśleniu, z własnego rozmysłu i na własna odpowiedzialność, tak by człowiek nieustannie się kształcący rozbudowywał również zbiór swoich miar. Wszystko, co powyżej powiedziano, prowadzi więc do ukoronowania w postaci następującej myśli: każdy ma sam siebie wychować, czyli wykształcić w świadomości własnej odpowiedzialności; każdy sam dla siebie jest nieskończonym zadaniem. Celem wychowania jednego człowieka przez drugiego jest skierować namysł jednostki tak daleko, by miała ona pełna jasność w ocenie własnych możliwości i roztropnie przyciagała ku sobie to, co korzystne, a odpychała to, co szkodliwe, by jednak czyniąc to, mogła w pełni odpowiadać przed samym soba, przed własnym wglądem w dobro i zło, prawdę i fałsz. W końcu jednak każdy musi wziąć swoje „wykształcenie” we własne ręce. W swoim punkcie kulminacyjnym myśl ta łączy się zatem z tradycją wieku osiemnastego. Myśl wychowawcza czasów Goethego wznosi się tutaj bowiem wysoko ponad płaskie pojęcia naszych dni i nabiera nowego sensu. Kształcenie człowieka nie jest mianowicie nadawaniem kształtu w takim sensie, w jakim kształtuje się domek ślimaka czy chmura, ani też w takim, w jakim kształtuje się dzieło sztuki pod dłonią artysty. Człowiek, w sposób zupełnie nieporównywalny z innymi, zyskuje kształt pod własnymi rękoma, moca własnego namysłu. To właśnie w ten jedyny w swoim rodzaju sposób przebiega kształcenie człowieka, który tak owocnie wykracza poza to, co poszczególne, ku całości świata. Dokonuje się to w procesie opisanym powyżej, w którym wysklepianie się ku nieskończoności prowadzi do rozrastania się na coraz szersze obszary, a ludzkie wnętrze wiedzie samo siebie ku coraz bogatszemu wglądowi i oglądowi tego całego świata. Jasne jest więc, że każdy spoczynek, każde zakończenie i ograniczenie oznacza powstrzymanie tego procesu ludzkiego kształcenia. Wobec tego myśl 
może jedynie pokładać nadzieję w zrozumieniu, że żadna historycznie uwarunkowana idealna wizja, żaden cel ostateczny, który zawsze jest w stanie objąc swoim zakresem tylko mały wycinek nieskończonego kosmosu, nie jest zadowalający z punktu widzenia intencji wychowania. Tylko bowiem człowiek sam, świadom, że jest dla siebie nieskończonym zadaniem, i w pełni odpowiedzialny, jest w stanie wypełnić zasady wychowania. Najtrafniejszego przykładu kogoś, kto bardzo poważnie pojmował to zadanie, dostarcza znowu sam Goethe. Bardziej niż ktokolwiek inny przywykł on upewniać się co do własnej drogi za pomoca tych samych miar, jakie stosował do oceny świata, by czynić to, co pożyteczne, a spokojnym ruchem uchylać się od tego, co szkodliwe. W ten sposób ukształtował się dojrzale, wspinając się na coraz to nowe wyżyny, świadom siebie. Gdy zaś w owej świadomości widział siebie i wszechrzecz, występowały one znowu razem i grecki kosmos powstawał na nowym poziomie, ogarniając wiecznym porządkiem Ja, Ty i świat. Tak kończyło się kształcenie człowieka Goethego, które sprawiało, że kosmos ów otwierał się przed nim w coraz to nowej pełni z coraz to nowych stron, lecz nie tylko jako jego życie, lecz i przez to, że budując jako twórca nowe rodzaje [bytów], dalej kształtował nieustannie siebie i świat. Co do tego, zaś, jak jeden rodzaj ze swoich wyżyn wskazuje nadchodzącemu drogę do wyjścia, spojrzeniu poznającego nasuwa się następujący obraz wychowania: lampadia echontes diadosusin allelois. '.

Vom Sehen in der Natur (p. 9-15, 19-29), (C) 1921 by Norbert Elias taken from FRÜHSCHRIFTEN, VOLUME 1 of Gesammelte Schriften, edited by Reinhard Blomert, published in 2002 by Suhrkamp Verlag.

Przełożyła Marta Bucholc

\footnotetext{
${ }^{1}$ Cytat z Państwa Platona, oznaczający dosł. „ci, którzy mają pochodnie, będa je przekazywali innym”(328A); w tłumaczeniu Władysława Witwickiego „pochodnie będą mieli w ręku i będa je sobie z rąk do rąk podawali” [przyp. tłum.].
} 